\title{
ON THE HISTORY OF STUDYING THE PROJECT METHOD IN RUSSIAN AND FOREIGN PEDAGOGICAL PRACTICE
}

\author{
Larisa Maslikhova ${ }^{1}$, Nadezhda Khakhulina ${ }^{2}$, Valery Barinov ${ }^{3}$ \\ ${ }^{1}$ Candidate of Historical Sciences, Associate Professor, Voronezh State Technical University, \\ 20 years of October street, 84, Voronezh, Russia, E-mail: maslikhova@vgasu.vrn.ru \\ ${ }^{2}$ Candidate of Technical Sciences, Associate Professor, Voronezh State Technical University, \\ 20 years of October street, 84, Voronezh, Russia, E-mail: hahulina@mail.ru \\ ${ }^{3}$ Doctor of economics, Professor, Voronezh State Technical University, \\ 20 years of October street, 84,Voronezh, Russia, E-mail: kafedravgasu@yandex.ru
}

\begin{abstract}
The paper considers the evolution of project-based learning on the example of different countries. The processes of implementation and implementation of project-based learning at different levels of higher education are studied and analyzed.
\end{abstract}

Keywords: project method, project activity, education system, educational process.

\section{INTRODUCTION}

Project-based learning is an unconventional learning model that seeks to better prepare students to address the real-world challenges they may face in their professional and other activities. Currently, this type of training is being experimentally introduced at the school level, and is also an integral part of the educational programs of secondary vocational and higher education. The widespread introduction of project-based learning was caused by the positive experience of its use and its advantage over other educational forms. In particular, many studies present conclusions that project principles in training have a positive impact on personal development, determine promising areas for further activity of students and teach creative thinking. the world around us is constantly changing, specialties that were actively required yesterday are not in demand today, and therefore, there is a need to prepare graduates for mobility, transformation of their knowledge, skills and abilities. In the near future, creativity is put in the priority of the competence of specialists.

\section{METHODOLOGY}

The methodological principles of the work are based on an interdisciplinary approach based on a combination of general scientific methods of cognition and special methods of information analysis. In particular, empirical methods were used - description, observation. Theoretical methods were also used, including the study and analysis of domestic and foreign practice of using the project method of training; systematization of research materials; modeling, generalization.

\section{DISCUSSION}

The method of projects as a source of development of the sphere of education and a kind of professional and pedagogical activity was formed for a rather long period.

The origins of this method go back to the Middle Ages. More than three hundred years ago, the Czech 
thinker, the founder of theoretical pedagogy Ya. A. Komensky expressed the idea of introducing a research incentive for the success of teaching into the activity of a teacher. He wrote: "People should be taught in the most important way that they draw knowledge not from books, but by observing the heavens and the earth themselves, oaks, beeches, that is, that they explore and learn the objects themselves, and not only remember other people's observations and explanations."

This idea was later developed in the works of many philosophers and teachers. in particular, J.J. Rousseau proclaimed the thesis that our first teachers of philosophy are our feet, hands, and eyes. he advised in the course of communication with the child to put questions accessible to his understanding and leave it to him to solve them. "Let him know, not because you have told him, but because he has understood; let him not learn science, but invent it." but all these concepts can only be considered as the origin of the idea of the project method. it was not widely used in educational practice.

Currently, it is traditionally believed that the project method originated in the early twentieth century during the revision of views on the general education system. Its founder is J. Dewey, who developed a new learning technology. The training was carried out in the course of practical activities of children, which was organized by the teacher, but planned by children in the classroom independently. In 1911, the American Bureau of Education legalized the term "project method", and it became widely used in educational literature and teaching activities. in 1919. - the american school department issued the recommendations "project method in education" and thus officially introduced this method into the practice of school education.

Schools organized according to the project method gave students the right to freely choose their classes. The curriculum was considered as a set of interrelated experiences. Students themselves chose the types of activities through which new knowledge was acquired. They also determined the content of the school curriculum. The teacher only assisted them in the execution of their plans. The main essence of the project was to stimulate the interest of children for certain problems, involving the possession of a certain amount of knowledge, and through project activities that address one or a number of problems showing the practical application of knowledge.

In general, their main ideas were as follows:

1. With great enthusiasm, the child performs only the activity that he has freely chosen himself;

2. The activity is not built in line with the academic subject;

3. Bearing on the immediate interests of the children;

4. True learning is never one-sided, and side information is important, etc.

The scientific justification of the project method was given in the works of W. Kilpatrick, E. Collings and others. In particular, V. Kilpatrick formulated the theoretical foundations of the project method, developed the first classification of projects in accordance with their goals. E. Collings conducted experimental research, proving the advantages of the project method over the traditional training system.

In 1920-30, the intensive introduction of the project method into pedagogical practice on a scientific basis began. E. Parkhurst organized the cooperation of students of different classes, stages of training, age groups; stimulated independent work of students in groups, advocated the preparation of an individual work plan or schedule of students. K. Washburn paid special attention to the connection of training with practical activities, integration of academic disciplines, laboratory work. R. Bertrand used the method of projects in the system of free education without marking with differentiation at the secondary level of education. O. Decroly organized the study of different school disciplines as part of one topic (the method of the center of interests). $\mathrm{S}$. Frenet used the project method as a means of stimulating the learning process (technology of free labor), etc.

Since the late 1930s and up to the early 1960s, there has been a decline in interest in the project method in the theory and practice of education. It is not actually used anywhere.

The revival of the project method, as well as its international spread, began in the 1960s. New directions in project training appeared. Since the late 1980s. New technologies of the project method were considered, first of all, from the point of view of receiving and processing information. In the late 1980s, B. Schlesinger used the project method in the "School without Walls". At the same time, the social significance of project activities is weakened in favor of individualization and personal participation.

In Russia, the origin of the project method in teaching also occurs at the beginning of the twentieth century. In 1905, a group of teachers led by S. T. Shatsky made an attempt to use project methods in teaching. 
Under his leadership, a whole group of Russian teachers worked to introduce the method in question into educational practice. It was reflected in the ideas of Soviet teachers. Kagarov analyzed the experience of implementing the method of projects in Russia and abroad and formulated its distinctive features: reliance on the interests of children, copying themes from adult life, the leading role of creativity and independence.

In the 1920s and 30s, certain elements of the project method were used in the following pedagogical directions and forms of organizing educational activities: labor school-identification of the nature of children's giftedness, practical labor activity aimed at the final result; research method-transition from a class-based system to a free educational activity of the child; studio system-independent work in groups with the distribution of roles to achieve a common goal in laboratories, as well as outside school, etc.

By the 1940s, the project method had disappeared from school practice. modern researchers of the history of russian pedagogy note that the prevalence of the project method in school in the 1920s led to an unacceptable drop in the quality of education. the result was the prohibition of the use of this method in training in the soviet union. The reasons for this were: the lack of training of teachers to work with projects, the lack of developed methods of project activity, excessive enthusiasm for the project method went to the detriment of other methods, the cancellation of assessments and certificates, individual tests that existed before, were replaced by collective tests for each completed task.

Until 1965, the project method was not practiced in Soviet pedagogy, and since the mid-1980s, in connection with the transition to a personality-oriented approach to learning, it has become widely implemented in modern pedagogical practice. This was due to a new wave of interest in the ideas of free education, taking into account the personal factor in the education and upbringing of children. Since that time, quite a lot of works devoted to the project method have appeared in the periodical press (N. Yu. Pakhomova, E. S. Polat, I. Chechel, etc.). A number of schools adopt this method of teaching as the main one in their educational activities.

At the beginning of the XXI century, the project method was used in many educational institutions.

\section{RESULTS}

The project method as it is used today has inherited only a number of features of the original idea: taking into account the interests of students in the distribution of assignments within the group in the collective implementation of the project, the specific features of students ' activities and the functions of the teacher at different stages of joint activity. Modern innovations in project training can be considered a large number of types of projects, more detailed regulation of the teacher's activities at each stage, the predominance of theoretical material over practical.

\section{CONCLUSION}

Currently, the use of the project-based method of teaching is considered as one of the most important and promising technologies of the pedagogical process. It is believed that this method allows to rationally combine theoretical knowledge and their practical application to solve specific problems of the surrounding reality in the joint activities of students. project training helps to form the so-called project style of thinking, which combines the theoretical and practical components of human activity into a single system, which allows you to discover and realize the creative potential of the individual.

However, the introduction of project-based learning has a number of opponents, because along with the advantages, it also has significant disadvantages. According to the authors of a number of studies, the problems of implementing project-based learning appear already in school and are further developed at the stages of secondary vocational and higher education. Some researchers note the impossibility of using such an approach in the learning process at the present stage, and most often indicate the following problems:

1) The unavailability of personnel;

3) The need for a radical restructuring of the organization of the learning process;

4) Unavailability of students, etc.

Nevertheless, project-based learning is a flexible model of education that adapts to the requirements of the time, capable of developing competencies that are in demand in the future. 


\section{REFERENCE LIST}

Babansky Yu. K. (1985). Methods of teaching in a modern comprehensive school. Moscow. (in Russian).

Vasilyeva A. M. Rak E. V. (2016). Stages of formation of project activity in the university //Scientific notes of the Orel State University. No. 4(73). Pp. 246-248. (in Russian).

Elizarova E. A. (2012) Essential analysis of project activity // Bulletin of the Samara State Technical University. Series: Psychological and pedagogical sciences. (in Russian).

Matyash N. V. (2000) Psychology of project activity of schoolchildren in the conditions of technological education / Edited by V. V. Rubtsov. - Mozyr: Reef "White Wind". 285 p. (in Russian).

Pakhomova N. Yu. (2003) Method of the educational project in an educational institution: A manual for teachers and students of pedagogical universities. Moscow. 110 p. (in Russian).

Penkovsky E. A. (2007) Project Method in Russian and foreign pedagogical theory and practice: on the basis of comparative analysis. Dis. ... candidate of pedagogical sciences. Yekaterinburg. 217 p. (in Russian).

Polat E. S., M. Yu. Bukharkina, M. V. Moiseeva, A. E. Petrova. (2004) New pedagogical and information technologies in the education system", Moscow (in Russian).

Prokopyeva N. I (2004).. Project-based learning in foreign education. To the question of formation and development // Siberian teacher. No. 2 (32). (in Russian).

Maslikhova L., Pogorelsky A., Boymatov U. (2020). Educational culture as an integral social phenomenon // 7th INTERNATIONAL CONFERENCE ON EDUCATION AND SOCIAL SCIENCES Abstracts \& Proceedings. PP. 221-225. (in English).

Khakhulina N.B., Trukhina N.I., Ivanov B. T. (2020). He role of competence approach in formation of functional literacy of learners. // 7th INTERNATIONAL CONFERENCE ON EDUCATION AND SOCIAL SCIENCES Abstracts \& Proceedings. Pp. 128-133. (in English). 